\title{
Electoral Behavior in The Electability of Presidential and Vice Presidential Candidates in The 2019 Elections
}

\author{
Ferdhiman P. Barigunaa*; Affan Sulaeman ${ }^{\mathrm{b}}$; Wawan Budi Darmawanc \\ abcUniversitas Padjajaran, Indonesia
}

\begin{tabular}{l}
\hline Information Article \\
\hline History Article \\
Submission : 16-02-2021 \\
Revision : 26-02-2021 \\
Acepted : 03-03-2021
\end{tabular}

\section{DOI Article:}

10.24905/jip.6.1.2021.1322

\begin{abstract}
A B S TRACT
This study aims to explain how factors, such as social and religious status, candidate figures, party identity, social and conventional media interactions, issue and program orientation, support of influential figures, and funds affect voter behavior in the 2019 Presidential and Vice Presidential Elections, to be precise in Ibun District. The study of voting behavior was developed because party identification or party loyalty did not have a strong influence, while what happened was that there were social divisions that had strong ties to voter behavior. An interesting phenomenon occurred in Ibun Subdistrict since there was a significant change in the number of voters in the 2014 presidential election where Prabowo received more votes than Jokowi, while in 2019, Jokowi received more votes than Prabowo. The research method in this research was explanatory quantitative research methods by collecting data from the results of questionnaires and documentation. The structural equation model (SEM) analysis method was also carried out to determine the effect of the dependent variable on the independent variable. Based on the findings obtained from this research, the researcher found that four variables greatly influenced the electability of candidates, namely media, the intensity of volunteer visits, religion, and role models. Psychological, sociological, and rational factors map voter behavior so that this can be applied in Ibun Subdistrict. The psychological aspects are represented by the media and role models; the sociological aspect represented by religion, while the rational aspect is represented by the figure of the candidate. Therefore, to increase the electability of candidates, they should imoprove positive image in the media, the intensity of volunteer visits, social piety from religious factors, and relationships with local community leaders.
\end{abstract}

Keyword: Voting Behavior, Electivity, Presidential Election

(C) 2021 Published by Governmental Studies. Selection and/or peer-review under responsibility of JIP.

* Corresponding author

E-mail address: cecep.programdata@gmail.com 


\section{Jurnal Ilmu Pemerintahan: Kajian Ilmu Pemerintahan dan Politik Daerah, Vol. 6 (1), April 2021 - 14}

Ferdhiman P. Bariguna ${ }^{a}$, Affan Sulaeman ${ }^{b}$, Wawan Budi Darmawan ${ }^{c}$

\section{Introduction}

This choice is based on the interests and likes so strong in yourself or someone. On the other hand, ethnicity's influence can also affect voter behavior in making choices in the 2019 Presidential and Vice Presidential elections. (Kantohe \& Sumampouw, 2019). The voting behavior in elections has become a topic of curiosity for social researchers, both at home and abroad. This led to the study of electing behaviors growing in countries that already implement democracy, such as the UNITED Kingdom, France, the Netherlands, Canada, the United States, and Japan. According to Flanagan in his study of electoral behavior in Japan, it was found that there are social divides bind closely to voter behavior. At the same time, party identification or party loyalty do not have a strong influence (Flanagan, 1991).

The presidential election five years earlier, in 2014 to be precise, was also enlivened by primordial issues, such as ethnicity, religion, race, and inter-group. This issue is present through the media, both television, newspapers, and social media. This means that the media can be a watchdog of the ruler dominance in the news, but the television did not have the competence to judge the government and sole discretion. (Dani Fadillah, Luo Zheng Lin, 2019). One of the roles of the media is to polarize existing news, such as the research results of (Nur Habibi \& Sunjana, 2019) Less than a year before the Indonesia presidential election, however it appears that political polarization has strengthened in all strata of society.

The elections sent several important messages to politicians. First, leaders who are perceived as performing poorly will suffer at the polls. (Dagg, 2007) Populism in the 2019 presidential election increasingly dangerous with the rampant hoaxes based on slander or new which is not necessarily true exposed by supporting elements each Candidates. (Ardipandanto, 2020). Social media as part of the new media has provided a new understanding that power operates in all aspects of human life, included in the virtual space. (Mochamad Iqbal Jatmiko, 2019)

Apart from social media, the role of election administrators also has an impact on voter behavior. Voters' behavior in welcoming the implementation of voting by various program implementations are carried out by the KPU as the election organizer. (Fauzi, 2019) The allegations against candidates of descent from Communist Party of Indonesia (PKI), Chinese descent, and presidential candidates who did not perform Friday prayers indicate the use of these issues to influence voters. In the Presidential and Vice Presidential Elections held in 2019, incumbent candidate Joko Widodo took over as K.H. Maruf Amin's front-runner, while Sandiaga Salahuddin Uno became Prabowo Subianto's companion. This composition makes the issue map change again. The charismatic ulama who is also the Chairman of the Indonesian Ulama Council (MUI) advanced in the election. Whereas previously, the Prabowo camp was considered by many people because it was accompanied by ulama.

The 2019 Presidential and Vice Presidential elections still become political battle of senior figures in influencing the voters' choice of votes. Jokowi's stronghold is inseparable from the figure of Megawati Soekarnoputri, the Chairman of the 2014 and 2019 Election Winning Party, as a central figure. Meanwhile, the central figures in Prabowo's stronghold are senior politicians such as Amien Rais, who once led the People's Consultative Assembly (MPR) in the Reformation's early days. Besides, there is also a charismatic figure who became a central figure in 2017 in the DKI Pilgub, namely Habib Rizieq Shihab. The presence of influential figures who gave their support was also a color in the elections at that time, of course along with the figure of the candidate himself. 


\section{Jurnal Ilmu Pemerintahan: Kajian Ilmu Pemerintahan dan Politik Daerah, Vol. 6 (1), April 2021 - 15}

Ferdhiman P. Bariguna ${ }^{a}$, Affan Sulaeman ${ }^{b}$, Wawan Budi Darmawan ${ }^{c}$

The 2019 Presidential election is also considered a continuation of the 2014 election as it was attended by the same presidential candidates, Jokowi and Prabowo. This phenomenon is interesting to discuss by focusing on the comparison of data on candidate elections between 2014 and 2019 and the conditions that make voters then switch or maintain their support between the two candidates.

Based on the President of the Republic of Indonesia's general election, the vote acquisition of incumbent candidate Joko Widodo has increased compared to 2014. In 2014 - 2019, Jokowi received 2\% of the vote, while candidate Prabowo experienced a $2 \%$ increase in votes.

One of the phenomena of a significant change in voter views occurred in Ibun Subdistrict, Bandung Regency,West Java. Based on the 2014 Presidential Election data obtained from the KPU's official website page, candidates Prabowo Subianto - Hatta Rajasa pair gained a total number of 22,914 voters over Joko Widodo - Jusuf Kalla with a total of 22,882 votes. Prabowo - Hatta also won the highest vote in 6 villages, namely Tanggulun, Sudi, Mekarwangi, Lampegan, Talun, and Karyalaksana, with the largest difference in the number of voters in Lampegan Village, namely 2,503 votes for Prabowo - Hatta and 1,794 votes for Jokowi - Kalla.

However, there has been a significant change in the number of voters in the 2019 Ibun Sub-district elections for the presidential candidates which are still the same as the 2014 presidential elections, namely Prabowo Subianto and Joko Widodo. Previously, Prabowo received more votes than Jokowi in the Ibun subdistrict in the 2014 presidential election, but in the 2019 presidential election, Jokowi received more votes than Prabowo. If Prabowo previously received the highest votes in Lampegan Village in the 2014 presidential election with 2,503 votes, the result of the 2019 presidential election changed where
Jokowi received 2,363 votes, while Prabowo received 2,315 votes.

The change in voter participation in the Ibun sub-district is an interesting phenomenon to study. Based on data on the official page of Bandung Regency, Ibun Subdistrict is located in rural areas, which are mostly agricultural and textile industrial areas with an area of 1,230 ha rice field and 1,757 ha of forest. Rural areas are indeed one of the great opportunities for presidential candidates and vice presidential to win votes even though the dominance of urban residents in Indonesia is still greater than in rural areas. However, the countryside remains one of the strategic targets in this regard. Prospective voters from rural areas should be considered since Indonesian cultural roots and origins come from rural areas. By dominating rural areas, presidential and vice-presidential candidates can win votes that may affect the total votes.

Various conditions related to 2019 President Election create the characteristics of voters in determining the electability of presidential and vice-presidential candidates to be interesting to watch. This in turn can enrich the collection of studies on the selection of political candidates in the country. This study aims to explain how factors such as social status and diversity, candidate figures, party identity, social and conventional media interactions, the orientation of issues and programs, support of influential figures and funds can significantly influence voter behavior in the 2019 Presidential and Vice Presidential Elections in Ibun Subdistrict.

\section{Method}

The research approach applied was based on quantitative exploratory methods to test two variables. The explanatory research method was used as a research instrument to find causal relationships of free variables and bound variables. The relationship of the cause of choosing behavior in this case determines the choice of candidates in an election. The 


\section{Jurnal Ilmu Pemerintahan: Kajian Ilmu Pemerintahan dan Politik Daerah, \\ Vol. 6 (1), April 2021 - 16}

Ferdhiman P. Bariguna ${ }^{a}$, Affan Sulaeman ${ }^{b}$, Wawan Budi Darmawan ${ }^{c}$

analysis of the research data was conducted on similar data to explain causal relationships between variables by testing hypotheses. The purpose is to provide meaning and gather various facts related to the behavior of choosing and the choice of candidates in the 2019 presidential election.

Selected behavior variables and complete electability variables will be studied academically as well as empirically so that it can be accounted for in this study. By formulating an approach based on the problems raised in the previous chapter, researchers want to find out the pattern of voting behavior in the selection of candidates that occurred in the 2019 Presidential Election. This is done by analyzing the description of voter identification, such as political choices, political voters, economic, social, by gender, age, occupation, education, and the region as well as identifying the factors that are considered by voters in selecting candidates based on political party identification, funding support, the orientation of issues/programs, religion, candidate figures, and mass media.

Primary data is needed to analyze the phenomenon to achieve the objectives and formulation of the research. Primary data is taken because it is considered more representative and can describe phenomena that exist in the field directly. Researchers chose Ibun Subdistrict, Bandung Regency, as the research location as it has the phenomenon of electability switching, which originally won by Prabowo in 2014 but then was changed to Joko Widodo in 2019.

Table 1. Proportion of Respondents

\begin{tabular}{cccccc}
\hline \multirow{2}{*}{ Villages } & \multicolumn{2}{c}{ Total Voters } & Sample per & $\begin{array}{c}\text { Man in } \\
\text { Each } \\
\text { Village }\end{array}$ & $\begin{array}{c}\text { Woman in Each } \\
\text { Village }\end{array}$ \\
\cline { 2 - 5 } Ibun & Male & Female & 23 & 12 & 11 \\
\hline Laksana & 2970 & 2836 & 21 & 11 & 10 \\
\hline Dukuh & 2717 & 2627 & 21 & 11 & 10 \\
\hline Talun & 2350 & 2162 & 18 & 9 & 8 \\
\hline Pangguh & 3390 & 3171 & 25 & 13 & 12 \\
\hline Lampegan & 2672 & 2475 & 20 & 10 & 10 \\
\hline Neglasari & 1775 & 1685 & 13 & 7 & 6 \\
\hline Mekarwangi & 2538 & 2525 & 20 & 10 & 10 \\
\hline Sudi & 2294 & 2156 & 17 & 9 & 8 \\
\hline Tanggulun & 1412 & 1360 & 11 & 6 & 5 \\
\hline Cibeet & 2325 & 2268 & 18 & 9 & 9 \\
\hline Karyalaksana & 2673 & 2475 & 20 & 10 & 10 \\
\hline Tanggulun & 1412 & 1360 & 11 & 6 & 5 \\
\hline
\end{tabular}

Source: Research Data 


\section{Jurnal Ilmu Pemerintahan: Kajian Ilmu Pemerintahan dan Politik Daerah, Vol. 6 (1), April 2021 - 17 \\ Ferdhiman P. Bariguna ${ }^{a}$, Affan Sulaeman ${ }^{b}$, Wawan Budi Darmawan ${ }^{c}$}

The stratified random sampling method that was used for each population sample has an equal and representative opportunities. Furthermore, the determination of the number of samples was carried out using a sampling formula in which the heterogeneity variable was entered to get a description that can be represented in the mapping of public opinion (Eriyanto, 2007) as follows:

$$
\begin{aligned}
& \mathrm{n}=\frac{N Z^{2} P(1-P)}{N E^{2}+Z^{2} P(1-P)} \\
& \text { Description: } \\
& \mathrm{n} \text { : Number of samples } \\
& \mathrm{N} \text { : Population } \\
& \text { Z: Degree of Trust } 95 \%(1,96) \\
& \text { P: Heterogeneity }(0-0,5) \\
& \text { E: Margin of Error }
\end{aligned}
$$

Referring to this formula and based on the 2019 DPT data in Ibun District, it is known that there are 58,262 voters with an error range of $3 \%, 95 \%$ confidence level, and 0.25 heterogeneity, so the sample observed was 226 samples. In order to comply with the rules of multistage random sampling, the next step is to divide proportionally based on gender and the village from which the sample was selected. The proportions obtained are as follows in Table 1 above.

The data collection techniques used in this study were questionnaires and documentation. In the next step, observations in the field generated data which was then processed through SPSS-17 (Statistical Package for Social Science) and Stata.
The analysis was done through Structural Equation Model (SEM) method. This method was chosen because of the large number of variables while the number of observed samples was limited. The aim was to find out how the influence of the relationship between the independent variables and the dependent variables.

\section{Results and Discussion}

\section{Analysis of Reliability and Validity Test}

The first step taken to analyze the variables studied was to find out how to advance each variable's reliability and validity.

This reliability and validity test found indicators that determine the reliability of a variable.

Through the reliability tests, the Cronbach Alpha number of each variable whose default should be greater than 0.5 was found. The validity test showed the number of correlations to the total variable items whose standard was more significant than 0.4 in each variable.

Table 2 below shows that each variable

\begin{tabular}{|c|c|c|c|c|c|c|}
\hline Variable & Indicators & $\begin{array}{c}\text { Standardized } \\
\text { loadings } \\
\text { Reflective } \\
>0,4\end{array}$ & $\begin{array}{c}\text { Validity } \\
\text { Result }\end{array}$ & $\begin{array}{c}\text { Cronbach } \\
>0,5\end{array}$ & $\begin{array}{c}\text { Discriminant } \\
\text { validity } \\
\text { average } \\
\text { variance } \\
\text { extracted }\end{array}$ & $\begin{array}{c}\text { Reliability } \\
\text { Result }\end{array}$ \\
\hline \multirow{3}{*}{$\begin{array}{l}\text { Medsos } \\
\text { User }\end{array}$} & Facebook & 0,84 & Valid & \multirow{3}{*}{0,53} & \multirow{3}{*}{0,523} & \multirow{3}{*}{ Reliable } \\
\hline & Whats App & 0,829 & Valid & & & \\
\hline & Youtube & 0,42 & Valid & & & \\
\hline
\end{tabular}
studied is valid and reliable. After testing, it was found that the variables have reliability above 0.5 for Cronbach Alpha size, while for validity is above 0.4 for the total correlation size to the variable items studied.

Table 2. Validity and Reliability Test Data Processing Results 
Jurnal Ilmu Pemerintahan: Kajian Ilmu Pemerintahan dan Politik Daerah,

Vol. 6 (1), April 2021 - 18

Ferdhiman P. Bariguna, Affan Sulaeman ${ }^{b}$, Wawan Budi Darmawan ${ }^{c}$

\begin{tabular}{|c|c|c|c|c|c|c|}
\hline Variable & Indicators & $\begin{array}{c}\text { Standardized } \\
\text { loadings } \\
\text { Reflective } \\
>0,4\end{array}$ & $\begin{array}{c}\text { Validity } \\
\text { Result }\end{array}$ & $\begin{array}{c}\text { Cronbach } \\
>0,5\end{array}$ & $\begin{array}{c}\text { Discriminant } \\
\text { validity } \\
\text { average } \\
\text { variance } \\
\text { extracted } \\
\end{array}$ & $\begin{array}{c}\text { Reliability } \\
\text { Result }\end{array}$ \\
\hline \multirow{3}{*}{$\begin{array}{c}\text { Prabowo's } \\
\text { media }\end{array}$} & News Duration & 0,899 & Valid & \multirow{3}{*}{0,652} & \multirow{3}{*}{0,615} & \multirow{3}{*}{ Reliable } \\
\hline & Social Media PRB & 0,522 & Valid & & & \\
\hline & Info PRB & 0,874 & Valid & & & \\
\hline \multirow{3}{*}{$\begin{array}{l}\text { Jokowi's } \\
\text { media }\end{array}$} & News Duration & 0,923 & Valid & \multirow{3}{*}{0,678} & \multirow{3}{*}{0,639} & \multirow{3}{*}{ Reliable } \\
\hline & Social Media JKW & 0,474 & Valid & & & \\
\hline & Info JKW & 0,917 & Valid & & & \\
\hline \multirow{2}{*}{$\begin{array}{l}\text { Sering } \\
\text { Prabowo }\end{array}$} & Party Members PRB & 0,961 & Valid & \multirow{2}{*}{0,925} & \multirow{2}{*}{0,93} & \multirow{2}{*}{ Reliable } \\
\hline & Volunteers PRB & 0,968 & Valid & & & \\
\hline \multirow{2}{*}{$\begin{array}{l}\text { Sering } \\
\text { Jokowi }\end{array}$} & Party Members JKW & 0,94 & Valid & \multirow{2}{*}{0,904} & \multirow{2}{*}{0,911} & \multirow{2}{*}{ Reliable } \\
\hline & Volunteers JKW & 0,969 & Valid & & & \\
\hline \multirow{2}{*}{ Party } & Volunteers & 0,951 & Valid & \multirow{2}{*}{0,903} & \multirow{2}{*}{0,911} & \multirow{2}{*}{ Reliable } \\
\hline & Party Members & 0,958 & Valid & & & \\
\hline \multirow{2}{*}{ Religion } & Lectures & 0,984 & Valid & \multirow{2}{*}{0,63} & \multirow{2}{*}{0,67} & \multirow{2}{*}{ Reliable } \\
\hline & Political Religion & 0,61 & Valid & & & \\
\hline \multirow{3}{*}{ Figures } & Community Leaders & 0,917 & Valid & \multirow{3}{*}{0,708} & \multirow{3}{*}{0,632} & \multirow{3}{*}{ Reliable } \\
\hline & Village Head & 0,951 & Valid & & & \\
\hline & Religious Leaders & 0,391 & Valid & & & \\
\hline \multirow{2}{*}{$\begin{array}{l}\text { Issues and } \\
\text { Programs }\end{array}$} & issue of Milenial & 0,83 & Valid & \multirow{2}{*}{0,597} & \multirow{2}{*}{0,712} & \multirow{2}{*}{ Reliable } \\
\hline & issue of Ulama & 0,858 & Valid & & & \\
\hline Swing Votes & Swing Votes & 1 & Valid & 1 & 1 & Reliable \\
\hline
\end{tabular}

Sources: Research Data

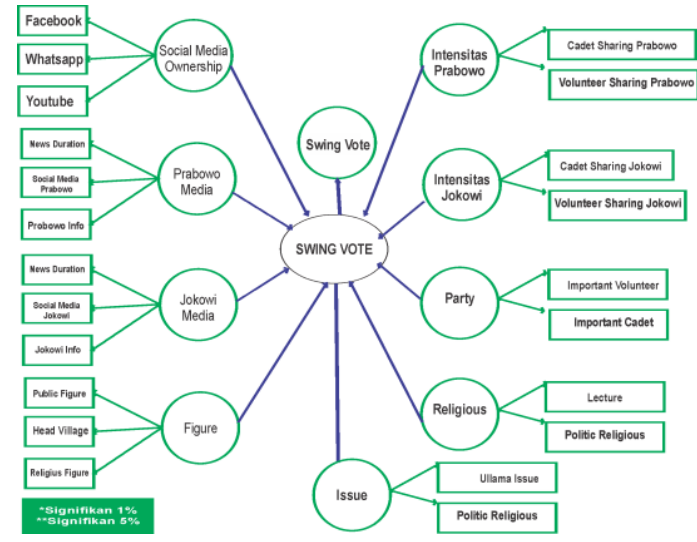

Picture 1. Path of Analysis of Choosing Behavior to Candidate Selection

From the table above, it is presented that each variable studied is valid and reliable because, after testing, the variable's reliability is found out to be above 0.5 for the size of Cronbach Alpha, and its validity is above 0.4 for the size of the total correlation to the variable items studied. Thus, the variables that can be continued to the next stage are social media, media that preach Prabowo, media that preach Jokowi, intensity of visits by Prabowo, intensity of visits by Jokowi, Party, Religion, Role models, issues, and programs.

As for dependent variables studied is the switch of votes from Prabowo in 2014 to Jokowi in 2019 to see changes in voter behavior towards the selection of candidates.

In the process of this data, it was found that pre-existing variables such as socio 


\section{Jurnal Ilmu Pemerintahan: Kajian Ilmu Pemerintahan dan Politik Daerah, Vol. 6 (1), April 2021 - 19}

Ferdhiman P. Bariguna ${ }^{a}$, Affan Sulaeman ${ }^{b}$, Wawan Budi Darmawan ${ }^{c}$

economics could not meet valid and reliable criteria, so that it is challenging to conduct inferential statistical tests for the next stage.

\section{SEM Analysis}

In conducting SEM analysis, each variable was reduced to one link which was the main factor in the analysis of the existing dependent variable. The following are the results of SEM analysis of the independent variables that are valid and reliable on the dependent variable that has been carried out:

Table 3. SEM Analysis

\begin{tabular}{lll}
\hline Variable & Magnitude & p-value \\
\hline \hline $\begin{array}{l}\text { User Media } \\
\text { Social }\end{array}$ & -0.072 & 0.274 \\
\hline $\begin{array}{l}\text { Prabowo's } \\
\text { Media }\end{array}$ & -0.331 & 0.095 \\
\hline $\begin{array}{l}\text { Jokowi's } \\
\text { Media }\end{array}$ & 0.22 & 0.275 \\
\hline $\begin{array}{l}\text { Sering } \\
\text { Prabowo }\end{array}$ & 0.26 & 0.06 \\
\hline $\begin{array}{l}\text { Serang } \\
\text { Jokowi }\end{array}$ & 0.082 & 0.549 \\
\hline Party & -0.063 & 0.456 \\
\hline Religion & -0.141 & 0.056 \\
\hline Figures & 0.166 & 0.017 \\
\hline Issues & -0.039 & 0.655 \\
\hline R2_a & 0.122 & \\
\hline
\end{tabular}

Sources: Research Data

From the results of the analysis, several points are obtained:

1. Social Ownership Variables negatively affect the Choice of Candidates..

2. Prabowo's Media Variables negatively and significantly affect the Selection of Candidates..

3. Jokowi's Media Variables positively affect the Candidate Selection.

4. Prabowo Intensity Variable negatively and significantly affects Candidate Selection.

5. Jokowi's Intensity Variable positively affects Candidate Selection.

6. Party Variables negatively affect candidate selection.
7. Religious Variables negatively and significantly affect the Selection of Candidates.

8. Character Variables positively and significantly affect the Candidate Selection.

9. Variable Issues and programs negatively affect Candidate Selection.

In conclusion, there are only four significant variables affect candidates' choice, namely Prabowo media, Prabowo Intensity, Religion, and Role Models. Therefore, what appears in the SEM analysis image scheme below.

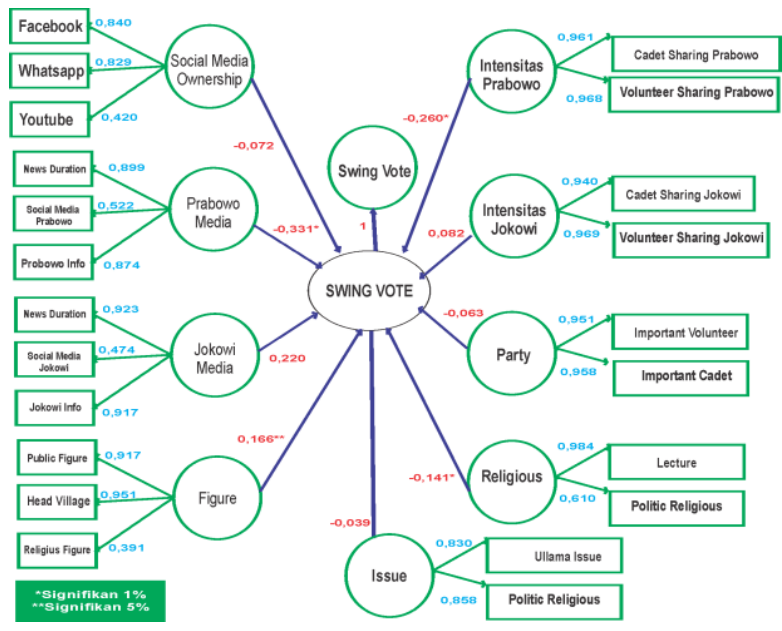

Picture 2. SEMAnalysis Voting Behavior towards the Selection of Presidential Candidates 2019 in Ibun Subdistrict, Bandung Regency

Several analyses arise from following inferential statistical results. The analysis is parsed from several independent variables that have a significant effect on the dependent variable. The first thing that can be seen is the media aspect. This section is quite interesting because when examined from a theoretical perspective, the media are found to be very influential in the votes given by the public during the presidential election. However, in this study, the media aspect that has the most significant influence in the presidential election is the media that contains news about Prabowo as the 2019 presidential candidate; Referring to a survey released by Median, Prabowo excelled Joko Widodo on social media (Putri, 2018). 


\section{Jurnal Ilmu Pemerintahan: Kajian Ilmu Pemerintahan dan Politik Daerah, Vol. 6 (1), April 2021 - 20}

Ferdhiman P. Bariguna, Affan Sulaeman ${ }^{\mathrm{b}}$, Wawan Budi Darmawan ${ }^{\mathrm{c}}$

Prabowo also ignored the data from the Cyrus Network which states that social media has reached its saturation point. Prabowo remains consistent with his actions on social media. It is still evident that the votes for Probowo in Ibun sub-district can be maintained for the 2019 presidential election. Based on the research conducted by Maulina \& Muttaqin (2020), it was mentioned that the image formed on social media that has a very positive effect is religious, assertive, loud, patriotic, polite, calm, integrity, intelligent and close. Prabowo's determination can be a driving force that Prabowo's media variables will maintain Prabowo's vote as in 2014, namely to keep voting for Prabowo in 2019. This analysis is in line with the approach in terms of rational factors put forward by Wettstein \& Wirth (2017) which states that mass media is very influence on the votes cast by the community. In political choices, emotionality also plays a role in the reasons why voters change their choice of candidates in the election.

The second variable is the intensity of Prabowo's party campaigning and trying to win more votes in Ibun sub-district. In this variable, the intensity of Prabowo's volunteer visits and the perception of the importance of a presidential candidate can still help maintain Prabowo's voice there. Hendri Satrio, a Political Observer, said that Prabowo's volunteer militancy in 2019 was classified as militant due to the actions of 212 alumni. Unfortunately, the statement had no scientific documentation. Other research states, volunteers supporting Prabowo in 2019 in Yogyakarta have three motives: material incentives, incentives-solidarity, and incentives-idealism. The most prominent motive in this regard is incentive-solidarity (Kahfi Kurnia \& Al-Hamdi, 2019).

The phenomenon occured in Ibun supports these statements and research, even though it cannot win Prabowo in this subdistrict. Analysis of the candidate figure, in this case, Prabowo figure, in line with the theory presented by (Niemi, R. G., Weisberg, H. F., Kimball, 1929). They stated that in the Controversies in voting behavior, that one's attitude is a reflection that will become a variable in determining political behavior. Thus, the psychological approach here focuses on three aspects: emotional ties to a particular party, orientation on issues, and orientation to candidates.

The third variable is religion. This variable is viewed based on the religious perception of each Muslim-majority person in this sub-district in his or her voting behavior towards candidates' choice. Religious variables are quite crucial in politics in Indonesia. In the 2019 presidential election, religion is indeed an essential factor for populism in taking the vote of voters regardless the danger of disintegration of the nation it may cause (Ardipandanto, 2020). Another study stated that Prabowo's victory was inseparable from the puritanical religious base. The base is so entrenched in West Java that religious factors are still the flagship for Prabowo. (Sihidi et al., 2020).

This is still a contributing factor to maintaining votes for Prabowo in Ibun from 2014 to 2019. The results of the analysis of these third variables are in line with the approach of the behaviour theory of choosing based on sociological factors. It is explained that social characteristics and social groupings have a significant effect in determining one's choosing behavior as well as religion as an essential component in determining political choices. Gerald Pomper explained the signification of social grouping in the study of voting behavior by dividing it into two variable positions: the economic-social state variables of voters and voters' families. According to his statement, the situation has a significant association with one's voting behavior. The ambience of family politics, such as parents' political choices (father and mother) will influence the child's political choices. Such 


\section{Jurnal Ilmu Pemerintahan: Kajian Ilmu Pemerintahan dan Politik Daerah, Vol. 6 (1), April 2021 - 21 \\ Ferdhiman P. Bariguna ${ }^{a}$, Affan Sulaeman ${ }^{b}$, Wawan Budi Darmawan ${ }^{c}$}

situations may include housing, social class, demographic characteristics, including beliefs (Uusitalo et al., 1993). According to Franklin as quoted by (Lipset, S, 1995), it is stated that some sociological ties like this theoretically are still related to the behavior of choosing (Lipset, S, 1995). A research about another aspects that should be more considered from the analysis of religious variables determines the choice of candidates was done by (Geertz, 1960). In his study, it is mentioned that religious has relation with political behavior in Indonesia since it has been initiated since long ago. Specifically, Geertz mentioned about the influence of "flow" in rural communities' political behavior in Java. This concept of "tradition" is a mindset formed by cultural and religious influences.

In the context of Javanese society, the fourth variable is the support of role models. This was the key to Jokowi's significant victory in Ibun sub-district. Although religious factors was more supportive of Prabowo, but religious leaders and community leaders directed the people in Ibun to vote for Jokowi. Religious figures, especially those who are part of NU, have directed their support to Jokowi, especially since the vice president candidate, Ma'ruf Amin, is a Kiai NU and a Sundanese. Mass mobilization by religious leaders played a significant role in Jokowi's victory in the 2019 presidential election in Ibun sud-district. Besides, Golkar who previously supported Prabowo in 2014 switched to Jokowi during the 2019 presidential election. In fact, the strongest party base in Ibun District is Golkar as the winner of the election at the sub-district level. With a robust patron-client system, Jokowi's victory was inevitable, even more significant than Prabowo's victory in Ibun in 2014. In the 2019 elections, one of the winning phenomena due to the patron-client factor was the victory of the Golkar Party in the country, to be precise in the Tanah Datar Regency, West Sumatra.(Ansyari et al., 2019).
This is also supported by the opinion of Aspinall \& Berenschot, (2019) that patronclients are still dominant in Indonesian politics. The public still listens to the directions of the closest community leaders to make political choices in their community. The analysis by applying the psychological factor approach is in line with the statement put forward by Sulaeman which states that the role model support variable greatly determines voter behavior in selecting candidates. Voter behavior in Indonesia is influenced by the identification of political parties, leadership factors, the role of the mass media, and funds' support. Besides, leadership factors also have differences due to typical patron-client patterns in Indonesia. Mass media and funding support became a new factor that emerged along with opening the post-reform democracy tap in Indonesia.

\section{Conclusion}

There is an interesting phenomenon from the election of the President of Indonesia in 2019. The hard work of volunteers during the campaign period, the piety of the Presidential candidates, and religious figures who are role models for the people who support the Presidential candidates are several factors that influence the vote choices given by the community. Things like this can be categorized that people who are voters are still influenced by sociological motivations in choosing their role models, such as religious role models for kiai and ulama. Furthermore, Presidential candidates can use rational factors in their campaign.

\section{References}

Ansyari, I., Harsasto, P., \& Fitriyah, F. (2019). Article Analisis Patron Klien Terhadap Kemenangan Partai Golkar Kabupaten Tanah Datar Sejak Reformasi Irvan Ansyari* Priyatno Harsasto. Indonesian Journal of Religion and Society (Vol. 01). [Crossref]

Ardipandanto, A. (2020). Dampak Politik Identitas Pada Pilpres 2019: Perspektif 


\section{Jurnal Ilmu Pemerintahan: Kajian Ilmu Pemerintahan dan Politik Daerah, Vol. 6 (1), April 2021 - 22}

Ferdhiman P. Bariguna, Affan Sulaeman ${ }^{\mathrm{b}}$, Wawan Budi Darmawan ${ }^{\mathrm{c}}$

Populisme The Impact of Identity Politics On President Election 2019: Populism Perspective Aryojati Ardipandanto. Jurnal Politica Dinamika Masalah Politik Dalam Negeri Dan Hubungan Internasional, 11(1), 43-63. [Crossref]

Aspinall, E., \& Berenschot, W. (2019). Democracy for sale: Elections, clientelism, and the state in Indonesia.[Crossref]

Dagg, C. J. (2007). The 2004 elections in Indonesia: Political reform and democratisation. Asia Pacific Viewpoint, 48(1), 47-59. [Crossref]

Dani Fadillah, Luo Zheng Lin, D. H. (2019). Social Media and General Elections in Malaysia 2018 and Indonesia 2019. KOMUNIKASI, II(01), 1-7.[Crossref]

Eriyanto, A. (2007). Sampling Technique-Public Opinion Analysis. Yogyakarta: LKiS Pelangi Aksara.

Fauzi, A. M. (2019). Perilaku Pemilih Menjelang Pemilu 2019. Journal of Islamic Civilzation, 40-48.[Crossref]

Flanagan, S. C. (1991). The Japanese voter. Yale University Press.

Geertz, C. (1960). The Javanese Kijaji: The changing role of a cultural broker. Comparative Studies in Society and History, 2(2), 228-249.

Kahfi Kurnia, R., \& Al-Hamdi, R. (2019). Motif Dukungan Relawan Independen Terhadap Elektabilitas Prabowo-Sandi Pada Pilpres 2019: Studi Atas Gerakan Milenial Indonesia (Gmi) Yogyakarta. Jurnal Profetik Politik, 7(2), 229-249. [Crossref]

Kantohe, S. A., \& Sumampouw, R. (2019). Perilaku Pemilih dalam Pemilihan Presiden Dan Wakil Presiden Republik Indonesia Tahun 2019 (Suatu Studi Di Kelurahan Taas Kecamatan Tikala Kota Manado ), 2019, 1-15.

Lipset, S, M. (1995). The encyclopedia of democracy. Routledge.

Maulina, P., \& Muttaqin, M. (2020). Citra Politik Prabowo-Sandi dalam Pemilihan Presiden (Pilpres) 2019 di Akun Media Sosial Instagram. Interaksi: Jurnal Ilmu Komunikasi, 9(1), 40-50.[Crossref]
Mochamad Iqbal Jatmiko. (2019). Post - Truth , Media Sosial , dan Misinformasi : Pergolakan Wacana Politik Pemilihan Presiden Indonesia Tahun 2019. Jurnal Tabligh, 20(1), 21-39.[Crossref]

Niemi, R. G., Weisberg, H. F., Kimball, D. (1929). Controversies in voting behavior (5th ed.). Washington DC: CQ Press.

Nur Habibi, M., \& Sunjana. (2019). Analysis of Indonesia Politics Polarization before 2019 President Election Using Sentiment Analysis and Social Network Analysis. International Journal of Modern Education and Computer Science, 11(11), 22-30. [Crossref]

Putri, Z. (2018). Survei Median: Prabowo Ungguli Jokowi di Media Sosial.

Sihidi, I. T., Roziqin, A., Dedik, \&, \& Suhermanto, F. (2020). Pertarungan Populisme Islam dalam Pemilihan Presiden 2019. JIIP: Jurnal Ilmiah Ilmu Pemerintahan, 5(2), 174-189. [Crossref]

Uusitalo, H., Ringen, S., Hansen, E., \& Erikson, R. (1993). Welfare trends in the Scandinavian countries.

Wettstein, M., \& Wirth, W. (2017). Debate Media Effects: How Media Influence Voters. Swiss Political Science Review, 23(3), 262-269. [Crossref]

\section{Author Profile}

Ferdhiman P. Bariguna is an investment advisor in the West Java Provincial Government, then his some researchs scopes focusing in regional politics, and public policy.

Affan Sulaeman is a lecturer in the Doctoral Program of Political Science Universitas Padjadjaran Bandung. On the other hand authors also active in several research in the field of political science and public policy.

Wawan Budi Darmawan is a lecturer in the Doctoral Program of Political Science Universitas Padjadjaran Bandung and active in research in scope of international relations and political relation 